\title{
Response to "Adjuvant vitamin C in cardiac arrest patients undergoing renal replacement therapy: an appeal for a higher high-dose"
}

\author{
Angelique M. E. Spoelstra - de Man ${ }^{*}$ (D), Harm-Jan de Grooth, Paul W. G. Elbers and \\ Heleen M. Oudemans - van Straaten
}

Keywords: Vitamin C, Cardiac arrest, Pharmacokinetics, Continuous renal replacement therapy

We thank Honore et al. [1] for raising the issue of the optimal dose of vitamin $\mathrm{C}$ in cardiac arrest patients, especially those requiring continuous renal replacement therapy (CRRT). They propose to treat patients post-cardiac arrest with $6 \mathrm{~g}$ daily. However, the efficacy of vitamin $\mathrm{C}$ after cardiac arrest has not been settled yet, let alone the optimal dose. Up to now, only one small trial in septic patients compared two different doses: $200 \mathrm{mg} / \mathrm{kg} /$ day $(\sim 16 \mathrm{~g} /$ day) seemed superior to $50 \mathrm{mg} / \mathrm{kg} /$ day $(\sim 4 \mathrm{~g} /$ day $)$ [2]. All other studies in varying populations (but not after cardiac arrest) investigated a single dose ( $3 \mathrm{~g}$ up to $125 \mathrm{~g} /$ day). So, clinical studies on efficacy and dose in the cardiac arrest population are crucial before recommending an optimal dose. We are starting such a study (NCT03509662).

Honore et al. propose to double this dose to $12 \mathrm{~g}$ during CRRT based on three studies. Two of these studies included patients on intermittent chronic hemodialysis/diafiltration. One found a mean loss of $66 \mathrm{mg}$ vitamin $\mathrm{C}$ per day (200 mg/week) [3], the other did not report total loss. The only study in patients on CRRT (continuous venovenous hemofiltration $(\mathrm{CVVH}))$ reported a median loss of $93(0-$ 372) mg vitamin $C$ per day. Furthermore, the mean plasma concentration in the CRRT patients was not

\footnotetext{
* Correspondence: am.spoelstra@vumc.nl

Department of Intensive Care Medicine, Amsterdam UMC, Vrije

Universiteit Amsterdam, De Boelelaan 1117, 1081 HV Amsterdam, The Netherlands
}

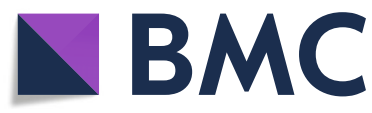

(C) The Author(s). 2018 Open Access This article is distributed under the terms of the Creative Commons Attribution 4.0 International License (http://creativecommons.org/licenses/by/4.0/), which permits unrestricted use, distribution, and

reproduction in any medium, provided you give appropriate credit to the original author(s) and the source, provide a link to the Creative Commons license, and indicate if changes were made. The Creative Commons Public Domain Dedication waiver (http://creativecommons.org/publicdomain/zero/1.0/) applies to the data made available in this article, unless otherwise stated. $(23-57) \mu \mathrm{mol} / \mathrm{L}$ vs $37(28-108) \mu \mathrm{mol} / \mathrm{L})$ [4]. This suggests that not the CRRT but the critical illness is the cause of the low vitamin $C$ concentrations.

We calculated vitamin $\mathrm{C}$ loss by $\mathrm{CVVH}$ in a patient from our pharmacokinetic study treated with $1 \mathrm{~g}$ intravenous vitamin $\mathrm{C}$ twice daily [5]. He had an average vitamin $C$ plasma concentration of $17.3 \mathrm{mg} /$ $\mathrm{L}(98.6 \mu \mathrm{mol} / \mathrm{L})$ during the 48 -h treatment period (AUC $832 \mathrm{mg} / \mathrm{L} \cdot 48 \mathrm{~h}$ ). Simultaneous plasma and post-filter measurements confirmed a sieving coefficient of about 1. At an effluent CVVH flow of $2 \mathrm{~L} /$ $\mathrm{h}$, this amounts to a total loss by CVVH of $830 \mathrm{mg}$ per day $(17.3 \mathrm{mg} / \mathrm{L} \cdot 2 \mathrm{~L} / \mathrm{h} \cdot 24 \mathrm{~h}), 41 \%$ of the administered dose. Removal by CRRT is therefore lower than removal by the native kidney $(1476 \mathrm{mg} /$ day; $74 \%$ of administered dose) in the four other patients not on CVVH treated with $2 \mathrm{~g} /$ day bolus infusions. The reason is that a CVVH dose of $2 \mathrm{~L} / \mathrm{h}$ corresponds to a clearance of $33 \mathrm{ml} / \mathrm{min}$, much lower than a native kidney clearance. The plasma vitamin $\mathrm{C}$ concentrations of this patient (patient 5; Fig. 1) were all within the normal range, suggesting that a dose of $1 \mathrm{~g}$ vitamin $\mathrm{C}$ twice a day may be sufficient to maintain normal plasma concentrations during CVVH.

In conclusion, vitamin $\mathrm{C}$ loss by $\mathrm{CVVH}$ does not seem to be higher than loss by the native kidney. So based on the scarce available data, it is not 


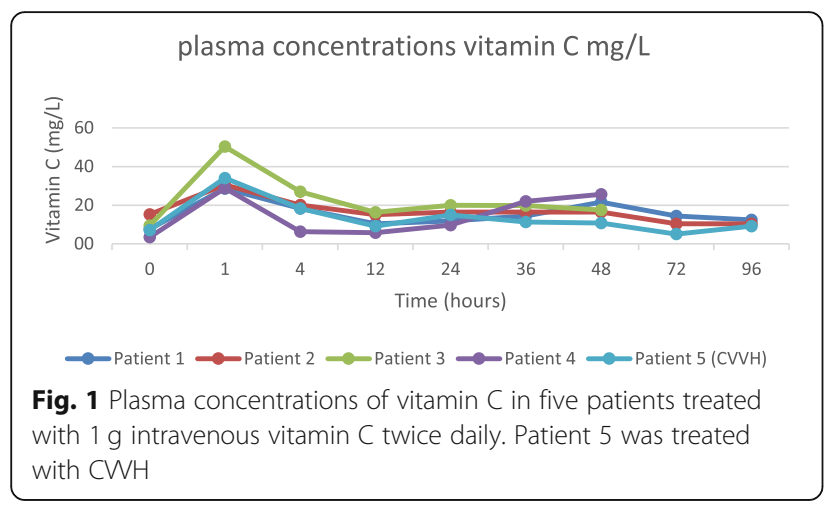

necessary to increase the vitamin $C$ dose during CVVH above $2 \mathrm{~g}$ /day when normal plasma concentrations are targeted. Whether higher concentrations are beneficial needs to be shown. In our RCT in cardiac arrest patients more pharmacokinetic data will be collected.

\section{Abbreviations}

CRRT: Continuous renal replacement therapy; CWH: Continuous venovenous hemofiltration

\section{Acknowledgements}

None.

\section{Funding}

We have received a grant from the Netherlands Organisation for Health Research and Development to perform an RCT with intravenous vitamin C in post-cardiac arrest patients.

\section{Availability of data and materials}

Available on request.

\section{Authors' contributions}

ASM drafted the original version of the manuscript. HJG, PWE, and HMO reviewed and revised the manuscript. All authors read and approved the final manuscript.

\section{Ethics approval and consent to participate}

Not applicable.

\section{Consent for publication}

All authors have reviewed the final version of the manuscript and approve the manuscript for publication.

\section{Competing interests}

The authors declare that they have no competing interests.

\section{Publisher's Note}

Springer Nature remains neutral with regard to jurisdictional claims in published maps and institutional affiliations.

Received: 8 September 2018 Accepted: 24 September 2018

Published online: 19 December 2018

\section{References}

1. Honore PM, De Bels D, Preseau T, Redant S, Attou R, Spapen HD. Adjuvant vitamin $C$ in cardiac arrest patients undergoing renal replacement therapy: an appeal for a higher high-dose. Crit Care. 2018;22(1):207.
2. Fowler AA III, Syed AA, Knowlson S, Sculthorpe R, Farthing D, DeWilde C, et al. Phase I safety trial of intravenous ascorbic acid in patients with severe sepsis. J Transl Med. 2014;12:32.

3. Morena M, Cristol JP, BosC JY, Tetta C, Forret G, Leger CL, et al. Convective and diffusive losses of vitamin $C$ during haemodiafiltration session: a contributive factor to oxidative stress in haemodialysis patients. Nephrol Dial Transplant. 2002;17(3):422-7.

4. Story DA, Ronco C, Bellomo R. Trace element and vitamin concentrations and losses in critically ill patients treated with continuous venovenous hemofiltration. Crit Care Med. 1999;27(1):220-3.

5. de Grooth HJ, Manubulu-Choo WP, Zandvliet AS, Spoelstra-de Man AME, Girbes AR, Swart EL, et al. Vitamin C pharmacokinetics in critically ill patients: a randomized trial of four IV regimens. Chest. 2018;153(6):1368-77. 